\title{
Deoxyribonucleic Acid Extraction and Quantification from Human Saliva Deposited on Foods with Bitemarks
}

Jamilly de Oliveira Musse ${ }^{1}$, Jeidson Antônio Morais Marques ${ }^{2}$, Vanessa Remualdo ${ }^{3}$, Ana Kelly Pitlovanciv ${ }^{4}$, Carlos Alberto Lima da Silva ${ }^{5}$, Francisco Corte-Real ${ }^{6}$, Duarte Nuno Vieira ${ }^{7}$, Walbert de Andrade Vieira ${ }^{8}$, Luiz Renato Paranhos ${ }^{9}$, Ana Teresa Corte-Real ${ }^{10}$

\begin{abstract}
Aim: The aim of this study is to evaluate the potential of deoxyribonucleic acid (DNA) recovery from bite marks in foods, in different collection types, from DNA quantification.

Materials and methods: The sample consisted of 80 swabs, obtained from 20 cheese pieces, bitten by the same person, using the double-swab technique in the center and the periphery of the bite. A statistical analysis was carried out using Statistical Package for the Social Sciences (SPSS) statistical software version 20.0, with values of $p<0.05$ being considered statistically significant.

Results: The DNA was recovered in all cheese pieces, regardless of the collection types and the bite region. However, the comparative analysis of DNA recovery potential in the four swabs allowed us to infer that the collections in the central region of the bite (DC and WC) were the ones that presented better precision, in addition to extracting a higher DNA concentration, the dry swab being in the center of the bite which presented better results.

Conclusion: The results proved the effectiveness of the double-swab technique for collecting genetic materials in bite marks; however, in the food used, a single collection at the center of the bite would be enough, optimizing the resources and time needed for the analysis.

Clinical significance: Due to the difficulties of physically comparing a site of a skin lesion and the dental arches of the suspect, the evidence of DNA in saliva has been used to indicate the perpetrator of the bite. In addition, the collection, preservation, and isolation of saliva DNA can be done at low cost and provide flexibility for clinical and laboratory workflow.
\end{abstract}

Keywords: Bite marks, DNA, Forensic odontology, Legal dentistry.

The Journal of Contemporary Dental Practice (2019): 10.5005/jp-journals-10024-2555

\section{INTRODUCTION}

Bite mark is the lesion produced by human or animal teeth in the body, in food, in human garments, and other objects, resulting from the vigorous application of the teeth to a substrate that is capable of being deformed. . $^{1-3}$

Given the frequency with which these pieces of evidences are found, the study of dental impressions in Legal Dentistry has been increasingly important, since the reports in the literature point to bite marks as expert elements for the identification of aggressors, victims, and criminals, ${ }^{1}$ and their analysis can be done through the study of physical (metric analysis and image overlapping) and biological (genetic analysis) evidence. ${ }^{4,5}$ The latter has been an important resource in the courts in elucidating crimes involving bites, where the uniqueness of human dentition through physical evidence was questioned. ${ }^{6}$

The biological evidence, deoxyribonucleic acid (DNA) present in the saliva, can be used to elucidate crimes involving cases of physical, sexual, and homicide violence, also being present in objects and foods found at the crime scene, having been recorded in the literature the occurrence of bites in apples, ${ }^{7}$ cheese, chocolates, oranges, cucumbers, biscuits, pies, chewing gum, bread, and others. ${ }^{8}$

Saliva collection in the bite marks can be done using techniques that use filter paper, single swabs, or double swabs. A study by Sweet et al., ${ }^{9}$ comparing the three collection methods, showed that the DNA recovery capacity by the double-swab technique was more effective (44.6\%), compared to the other methods, paper filter (17.4\%) and the single-swab technique (35.3\%).

\footnotetext{
1,2,5 Health Department, State University of Feira de Santana (UEFS), Feira de Santana, BA, Brazil

${ }^{3,4}$ Genolab Laboratory, Blumenau, SC, Brazil

${ }^{6,7,10}$ School of Medicine, Coimbra University, Coimbra, Portugal

${ }^{8}$ Department of Dentistry, Federal University of Sergipe (UFS), Aracaju,
} $\mathrm{SE}$, Brazil

${ }^{9}$ Area of Preventive and Community Dentistry, School of Dentistry, Federal University of Uberlândia, Uberlândia (UFU), Minas Gerais, Brazil

Corresponding Author: Jamilly de Oliveira Musse, Health Department State University of Feira de Santana (UEFS), Feira de Santana, BA, Brazil, Phone: +55 75 981371327, e-mail: musse_jo@hotmail.com

How to cite this article: de Oliveira Musse J, Marques JAM, et al. Deoxyribonucleic Acid Extraction and Quantification from Human Saliva Deposited on Foods with Bitemarks. J Contemp Dent Pract 2019;20(5):548-551.

Source of support: Nil

Conflict of interest: None

According to Francischini, ${ }^{10}$ the DNA extracted from forensic samples is often in a state of degradation, which affects the genetics analysis. In addition, such samples are commonly contaminated with microorganisms so that the extracted DNA may contain large amounts of nonhuman genetic material, leading to an overestimated DNA concentration by the standard method of ultraviolet light absorption at a wavelength of $260 \mathrm{~nm}$. Real-time PCR quantification has been applied for the identification

(O) The Author(s). 2019 Open Access This article is distributed under the terms of the Creative Commons Attribution 4.0 International License (https://creativecommons. org/licenses/by-nc/4.0/), which permits unrestricted use, distribution, and non-commercial reproduction in any medium, provided you give appropriate credit to the original author(s) and the source, provide a link to the Creative Commons license, and indicate if changes were made. The Creative Commons Public Domain Dedication waiver (http://creativecommons.org/publicdomain/zero/1.0/) applies to the data made available in this article, unless otherwise stated. 
of human DNA in forensic samples, since it presents some advantages in relation to qualitative PCRs as easy technique, greater sensitivity and precision, reproducibility and accuracy, analysis speed, better quality control in the process, and lower contamination risk. ${ }^{11}$

In this sense, the objective of this work was to evaluate the potential of DNA recovery from bite marks in cheese pieces, using different collection types, from DNA quantification.

\section{Materials and Methods}

The sample was composed of 80 swabs, obtained from the DNA collection of 20 cheese pieces, bitten by the same perpetrator.

For the collection of epithelial cells in the bite, the double-swab technique was used, one moistened with saline solution and the other dried, according to Sweet et al. ${ }^{9}$ In each bite, four forms of swabs' collection were done: wet from the periphery of the bite (WP); dry from the periphery of the bite (DP); wet from the center of the bite (WC); and dry from the center of the bite (DC). After drying at room temperature for 30 minutes, they were packed in paper envelopes and stored for 24 hours.

The DNA was extracted by the phenol-chloroform method. The DNA samples were amplified and quantified by real-time PCR using the Quantifiler Human DNA Quantification Kit (Applied Biosystems). The analysis of the reaction was performed by the IQ-5 Program (Biorad), followed later by calculating DNA concentration of the samples.

For the data analysis, the SPSS statistical program version 20.0 (IBM Statistics, USA) was used to calculate the mean, standard deviation, and variation coefficient of the DNA concentrations for each collection type. In addition, "box plot" charts were compared to analyze the symmetry of the data sets, followed by the Wilcoxon Signed Ranks Test. Spearman's rank correlation coefficient was used to analyze the correlation between swabs obtained from the same region. Statistically significant results were those that presented $p$ value $<0.05$.

\section{Results}

The DNA was recovered in all pieces of cheese, regardless of the collection types and the bite region. However, the comparative analysis of DNA recovery potential in the four types of swabs

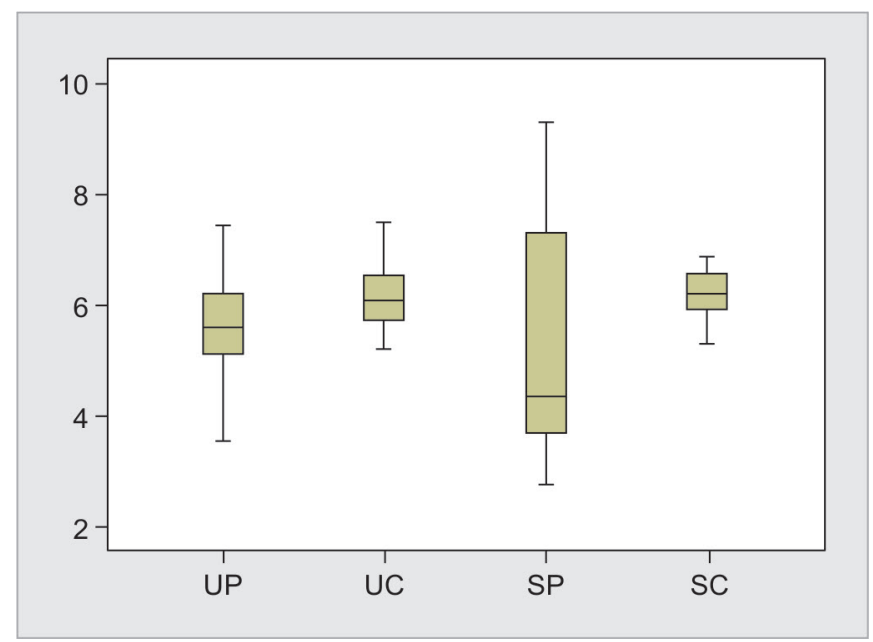

Graph 1: Comparison between DNA concentrations in different collection types (WP, WC, DP, and DC)
Table 1: Comparison of mean, standard deviation, and variation coefficient in different swab types

\begin{tabular}{lllll}
\hline $\begin{array}{l}\text { Collection } \\
\text { types }\end{array}$ & Mean & $\begin{array}{l}\text { Standard } \\
\text { deviation }\end{array}$ & $\begin{array}{l}\text { Variation } \\
\text { coefficient (\%) }\end{array}$ & $N$ \\
\hline WC & 6.1620 & 0.58655 & 9.51 & 20 \\
DC & 6.1970 & 0.45325 & 7.31 & 20 \\
WP & 5.5855 & 0.97603 & 17.47 & 20 \\
DP & 5.3370 & 2.08369 & 39.04 & 20 \\
\hline
\end{tabular}

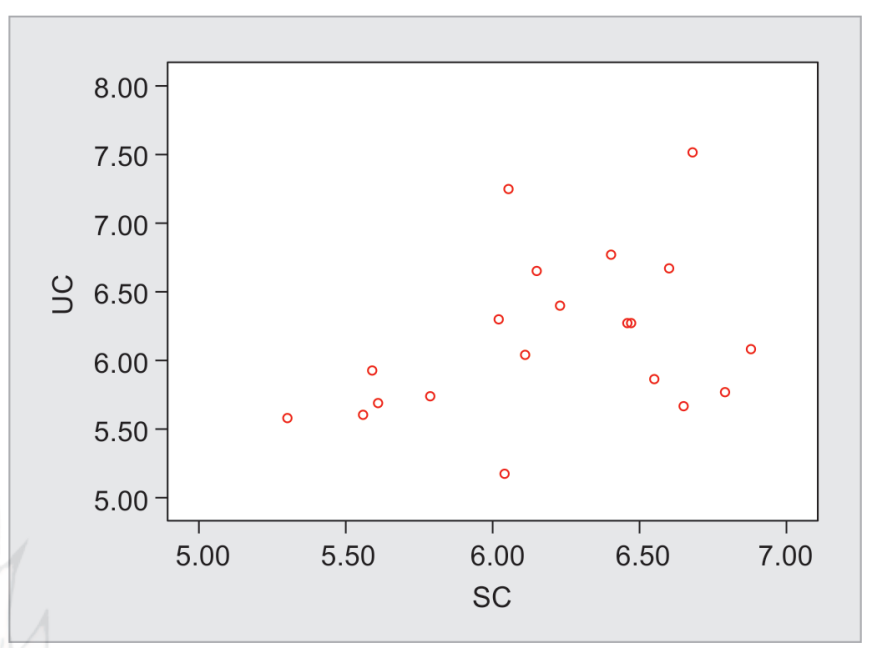

Graph 2: Correlation between DNA concentrations in wet (WC) and dry (DC) collections, carried out at the center of the bite

allowed us to infer that the collections in the central region of the bite (DC and WC) were the ones that presented the best reproducibility, extracting a higher DNA concentration (Graph 1), the dry swab being in the center of the bite which presented better results.

The mean concentration of DNA obtained from collections at the center of the bite was close and there was no great discrepancy in relation to the values of the standard deviation. In contrast, the swabs at the periphery of the bite, despite having similar mean values, showed a significant difference in the values of the standard deviation, which can be ratified by also analyzing the variation coefficients corresponding to each collection type (WC $=9.51 \%$, $\mathrm{DC}=7.31 \%, \mathrm{WP}=17.47 \%$, and DP $=39.04 \%$ ) (Table 1$)$.

To evaluate the intensity of the relationship between the swabs referring to the same region, center, and periphery of the bite, the Spearman's rank correlation coefficient was used. In this sense, Graphs 2 and 3 suggest a tendency of correlation between the concentrations of DNA coming from wet and dry swabs at the center of the bite and the absence of correlation in the periphery.

\section{Discussion}

Human bite mark evidence is often found in violent crimes. It is difficult to collect saliva stains from the skin, clothing, paper, or other inanimate objects, since it remains invisible and the substrate on which the saliva is deposited, especially the skin, cannot be subjected directly to the extraction procedures. ${ }^{12}$

Due to the difficulties of physically comparing a site of a skin lesion and the dental arches of the suspect, the evidence of DNA in saliva has been used to identify the perpetrator of the bite..$^{13}$ In addition, the collection, preservation, and isolation of saliva DNA 


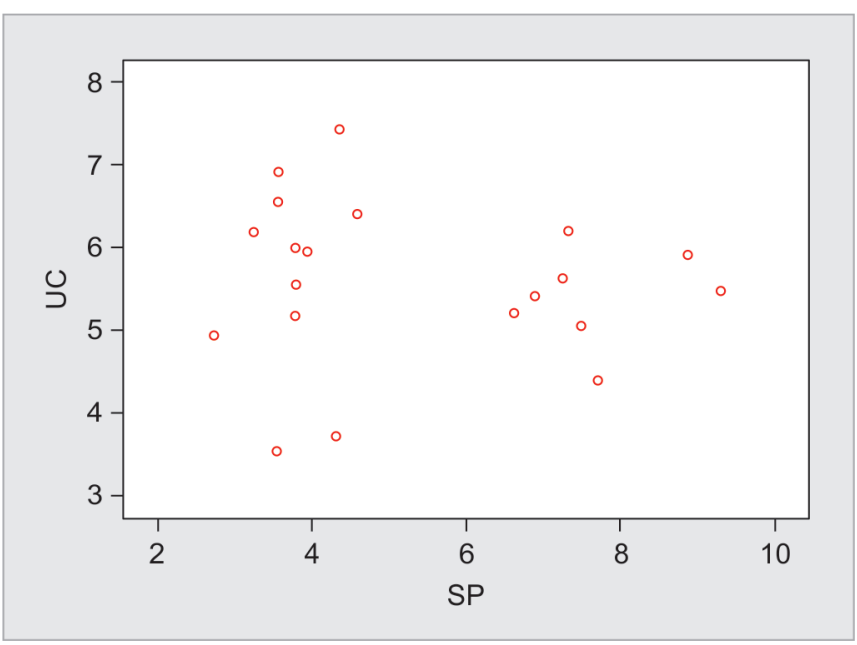

Graph 3: Correlation between DNA concentrations in wet (WP) and dry (DP) collections, carried out at the periphery of the bite

can be done at low cost and provide flexibility for clinical and laboratory workflow. ${ }^{14}$

In the case of food, Saxena and Kumar ${ }^{12}$ also pointed out that biological evidence in the bite marks' analysis is a potential source of perpetrator identification when the physical comparison is problematic, especially in the function of the food degradation, over time.

Marques et al. ${ }^{1}$ pointed out that for the technical-scientific analysis of bite marks in food, it is important to register them immediately, a good technique for collecting the impressions, and a thorough evaluation, through its own protocol, of all the pieces of evidences found, since the food is subject to considerable shrinkage and distortion, which may compromise dental impression study.

According to Almeida, ${ }^{15}$ food brands can provide more information compared to bite marks on the skin, since it does not involve the movement dynamics between the victim and the aggressor, resulting in less distortion and a better dental piece impression.

According to Elsie et al., ${ }^{14}$ the DNA in saliva comes from scaly cells of the oral mucosa and white blood cells. These DNAcontaining cells are collected and extraction can be carried out by several methods. Forensic studies have shown that the use of saliva that is deposited on imprints, bite marks, cigarette butts, marks, and imprints left on stamps and other objects can aid in individual identification.

However, the amount of saliva deposited in the skin and in food is usually very small in cases of bite marks, and it is necessary to use collection methods that result in the recovery of the maximum number of cells possible of the oral mucosa and that minimize any potential contamination.

Goetten ${ }^{16}$ stated that in order to collect this evidence, the double-swab technique has proven to be an effective method for DNA recovery both in the skin and in inanimate objects.

Sweet et al. ${ }^{9}$ compared the DNA recovery potential obtained with single- and double-smear techniques, finding a difference of 9.3\% between them, concluding that the double-swab technique, to recover saliva from human skin allows for the collection of a greater amount of DNA evidence than the classical methods studied. The authors believe that this fact happens due to the moisture present in the first cotton swab that rehydrates the majority of dry epithelial cells in the saliva, improving their adhesion to the dry swab cotton fibers.

Sweet and Hildebrand ${ }^{17}$ reported a case of identification of the biter, comparing the genetic profile of the suspect with cheese found at a crime scene, despite the suspicion of degradation of biological evidence, by the bacterial action on the cheese surface.

Anzai-Kanto et al. ${ }^{18}$ evaluated the reproducibility of the double-swab technique for DNA analysis of saliva collected on the skin. For this, 20 samples of saliva ( $\pm 2 \mathrm{~mL}$ ) of different volunteers were collected, and 5 samples were then drawn by another researcher, to deposit about $250 \mu \mathrm{L}$ of saliva in the researcher's arm simulating bites' cases. DNA extraction by organic method and PCR amplification, using 15 regions. The study found that the technique used to study saliva in skin bite marks was sensitive and efficient.

Nazir et al. ${ }^{5}$ using the single-swab wet technique in distilled water were able to recover DNA from 55 samples, including controls (positive and negative) and bitten fruit swabs. For this, the Chelex extraction method and the Quantifiler ${ }^{\circledR}$ DNA Quantification Kit were used to extract and quantify the samples. The DNA amplification was carried out in real-time PCR.

In this study, it was possible to recover DNA from all types of collections. However, those obtained in the central region of the bite presented more expressive results, with the dry swab at the center of the bite, which achieved better DNA recovery. These results corroborate with others in the literature on the applicability of the double-swab technique for collection in bite marks; ${ }^{18,19}$ however, it is evidenced that in foods used (cheeses), a single collection at the center of the bite would be enough, optimizing the resources and time needed for analysis. It is worth noting that the type of food, its consistency, and storage conditions can directly influence the potential for DNA recovery. In an attempt to optimize the results, cheese was chosen for being a food of uniform composition and smooth surface, with lower deformation potential.

Corte-Real et al. ${ }^{7}$ used the double-swab technique to recover the DNA of 14 apples, with the collection carried out at the periphery and at the center of the bite. Contrary to this research, the authors obtained more expressive quantification results in the collection carried out at the periphery of the bite. This difference may be directly related to the food type used, which may give the apple greater degradation factors in the center of the bite, unlike cheese.

Regarding the extraction method, in this research, the organic method was chosen. Barea et al., ${ }^{20}$ after comparing extraction methods, stated that the extractions that presented the best quantitative results are those that used organic solvents, phenol and chloroform.

Elsie et al. ${ }^{14}$ stated that the organic extraction process is a wellestablished technique that removes and precipitates proteins from DNA using phenol-chloroform-isoamyl alcohol.

However, Nazir et al., ${ }^{5}$ working with bite marks in fruit, verified that the modified Chelex extraction method presented better results in comparison to the phenol-chloroform method and the traditional Chelex method.

Considering the potential for the degradation of the samples in the forensic context, this research was chosen by carrying out the amplification and quantification of the DNA by real-time PCR using the Quantifiler Human DNA Quantification Kit (Applied Biosystems).

According to Krenke et al., ${ }^{21}$ DNA quantification using a realtime PCR methodology (qPCR) provides a dynamic quantification that is superior to other methods, increasing the objectivity of the interpretation. This is because $\mathrm{qPCR}$ is a technique that 
simultaneously allows for inference about the quantity and quality of the DNA present in a sample, contributing to more effective decision-making. In addition, in this system, the amplification, detection, and quantification phases are fully automated, optimizing the working time. ${ }^{22}$

For Oliveira, ${ }^{23}$ the quantitative determination of DNA from a sample has an essential role in the suitable amplification and subsequent identification of the amplified products through commercial kits, due to the narrow range of DNA concentrations at which these essays have a higher efficiency, both the excess and the lack may compromise the result.

In this work, the concentration of DNA was considerable in all samples, presenting slightly larger results in the collections involving the swabs of the bite center, evidencing the importance of the incorporation of this laboratory phase in the forensic context, regarding, in the specific case of this work, the analysis of bite marks in food.

\section{Conclusion}

The comparative analysis of the potential for DNA recovery in the four swabs allowed us to infer that the collections in the central region of the bite ( $D C$ and $W C$ ) were the ones that presented the best reproducibility, extracting a higher concentration of DNA, the swab being dry in the center of the bite, which presented better results. The results proved the effectiveness of the doubleswab technique for collecting genetic materials in bite marks; however, in the feed used, a single collection at the center of the bite would be enough, optimizing the resources and time needed for analysis.

\section{Clinical Significance}

Due to the difficulties of physically comparing a site of a skin lesion and the dental arches of the suspect, the evidence of DNA in saliva has been used to identify the perpetrator of the bite. In addition, the collection, preservation, and isolation of saliva DNA can be done at low cost and provide flexibility for clinical and laboratory workflow.

\section{References}

1. Marques JAM, Cardoso PC, et al. Identificação de Marcas de Mordidas em Alimentos. Odont Soc 2007;9(2):17-23.

2. Sweet JD. Marks from teeth as forensic evidence the state the art. Cien Forense 2005;7:91-98.

3. Maior JRS, Braga Netto ABA, et al. A aplicação da fotografia em marcas de mordida. Int J Dent 2007;6(1):21-24.

4. Musse JO, Marques JAM, et al. Aplicação do DNA na analise de marcas de mordidas. In: Marques JAM, Galvão LCC, Silva M. Marcas de Mordidas. Feira de Santana: UEFS; 2007.
5. Nazir $S$, Wasim $M$, et al. DNA extraction and quantification from human saliva deposited on fruits with human bite. Adv Life Sci 2013;1:31-36.

6. Franco A. Unique or not unique? That is the question! - opinion article on a bitemark scope. RBOL 2015;2(2):126-131. DOI: 10.21117/ rbol.v2i2.36.

7. Corte-Real A, Silva DN, et al. Bitemarks in foodstuffs - Na approach for genetic identification of the bitter. Forensic Sci Int 2013;4: e340-e341.

8. Kaur S, Krishan K, et al. Analysis and identification of bite marks in forensic casework. Oral Health Dent Manag 2013;12(3):127-131.

9. Sweet $D$, Lorente $M$, et al. An improved method to recover saliva from human skin: the double swab technique. J Forensic Sci 1997;42(2):320-322.

10. Francischini L. Development and use of triplex real time PCR assay forhuman DNA quantification in forensic samples. Saúde, Ética Justiça 2013;18:72-78.

11. Novais CM, Alves MP. Uma inovação tecnológica da reação em cadeia da polimerase (PCR). Biotec Cien Desen 2004;13:4.

12. Saxena S, Kumar S. Saliva in forensic odontology: A comprehensive update. J Oral Maxillofac Pathol 2015;19(2):263-265. DOI: 10.4103/0973029X.164549.

13. Sinha M, Rao A. Genetics and Molecular Biology Techniques Applications in Forensic Dentistry-A Review. Int J Multidiscip Curr Res 2015;5:315-319.

14. Elsie BH, Shaju SS, et al. Comparison of DNA from different oral swabs and its application in DNA profiling. J Pharm Pharm Sci 2017;6(5):791-803. DOI: 10.20959/wjpps20175-9056.

15. Almeida CVS. Marcas de mordida e a identificação humana. Porto: Dissertação - Universidade Fernando Pessoa; 2012.

16. Goetten FS. Avaliação de lesões corporais em vítimas de mordeduras: uma revisão da literatura. Rev Bras Crimin 2014;3(2):41-45. DOI: 10.15260/rbc.v3i2.76.

17. Sweet $D$, Hildebrand $D$. Recovery of DNA from human teeth by cryogenic grinding. J Forensic Sci 1998;43(6):1199-1202.

18. Anzai-Kanto $E$, Hirata $M H$, et al. DNA extraction from human saliva deposited on skin and its use in forensic identification procedures. Braz Oral Res 2005;19(3):216-222. DOI: /S1806-83242005000300011

19. Sweet $D$, Lorente $M$, et al. Increasing DNA extraction yield from saliva stains with a modified Chelex method. Forensic Sci Int 1996;83: 167-177.

20. Barea JÁ, Pardini MAMC, et al. Extração de DNA de materiais de arquivo e fontes escassas para utilização em reação de polimerase em cadeia (PCR). Rev Bras Hematol Hemoter 2004;26(4):274-281. DOI: 10.1590/S1516-84842004000400008

21. Krenke BE, Nassif N, et al. Developmental validation of a real-time PCR assay for the simultaneous quantification of total human and male DNA. Forensic Sci Int Genet 2008 Dec;3(1):14-21. DOI: 10.1016/ j.fsigen.2008.07.004.

22. Heid CA, Stevens J, et al. Real time quantitative PCR. Genome Res 1996;6(10):986-994.

23. Oliveira ARR. Quantificação de ADN nuclear e ADN mitocondrial por PCR em tempo real. Portugal: Dissertação [Mestrado em Biologia Humana e Ambiente], Universidade de Lisboa; 2009. 